\title{
Catalyst Conversion Rates measurement on engine fueled with Com- pressed Natural Gas (CNG) using different operating temperatures
}

\author{
Marcin DZIEWIĄTKOWSKI*, Dariusz SZPICA** \\ *Bialystok University of Technology, Doctoral School, 45A Wiejska Str., 15-351 Bialystok; AC SA, 5042 Putku Piechoty \\ Str., 15-181 Bialystok, Poland, E-mail: m.dziewiatkowski@student.pb.edu.pl \\ **Bialystok University of Technology, Faculty of Mechanical Engineering, 45C Wiejska Str., 15-181 Biatystok, \\ Poland, E-mail:d.szpica@pb.edu.pl \\ crossref http://dx.doi.org/10.5755/j02.mech.30164
}

\section{Definitions / Abbreviations}

AMFA - Alternative Motor Fuels Act; ASC - Ammonia slip catalyst; ATDC - After top dead center; BSFC - Brake Specific Fuel Consumption; CA - Crank angle degrees; CAFÉ - Corporate Average Fuel Economy; $\mathrm{CH}_{4}-\mathrm{Me}$ thane; $\mathrm{CI}$ - Compressed ignition; $\mathrm{CNG}$ - Compressed Natural Gas; $\mathrm{CO}$ - Carbon monoxide; $\mathrm{CO}_{2}-$ Carbon dioxide; CVC - Constant volume combustor; DOC - Diesel oxidation catalyst; DPF - Diesel particulate filter; FTIR - Fourier transform infrared spectroscopy; GDI - Gasoline direct injection; GHGs - Greenhouse gases; $\mathrm{H}_{2}$ - Hydrogen; $\mathrm{HC}-$ Hydrocarbons; HCHO - Formaldehyde; HRR - Heat release rate; LNT - Lean NOx trap; LPG - Liquefied Petroleum Gas; $M$ - Torque; $n$ - Rotation speed; $\mathrm{N}_{2} \mathrm{O}-$ Nitrous oxide; NEDC - New European driving cycle; $\mathrm{NH}_{3}-\mathrm{Am}$ monia; $\mathrm{NO}_{\mathrm{x}}-$ Nitric oxides; $\mathrm{O}_{2}-$ Oxygen; OC- Oxidation catalysts; $P$ - Power; PFI - Port Fuel Injected; PM - Particulate matter; RDE - Real driving emissions test; SI - Spark ignition; $T$ - Temperature; TTW- Tank to wheel; WLTC Worldwide harmonized light vehicles test cycle.

\section{Introduction}

There is a plan in transport legislations to reach $\mathrm{CO} 2$ emission reduction $15 \%$ until 2025 and $37,5 \%$ until 2030 [1]. Attempts to meet increasingly stringent general standards related to GHGs [2] will form the basis for shaping the most recent Euro 7 emission [3]. This will most likely lead to the exclusion of the use of internal combustion engines used in classical transport as a single source of vehicle propulsion. This trend will force down transportation to switch drive train systems to hybrid types $[4,5]$ and electric drives [6], or to use $\mathrm{H}_{2}$ vehicles [7]. Special attention should also be paid to engines of non-road and working machines as well as ships $[8,9]$. One way to seek a solution to the emissions problem may be to use multiple fuels [10, 11], or fuels with lower carbon content, in engines [9, 12].

The most popular alternative fuels are LPG and CNG [13-15]. The use of these fuels in internal combustion engines is regulated by legislations 2014/94/EU, AMFA, CAFÉ and GHGs [16]. In the longer term, $\mathrm{H}_{2}$ is considered the fuel of the future, but the competition for its use is CNG, from which $\mathrm{H}_{2}$ can also be extracted.

Testing of an SI engine alternatively fueled with CNG showed a slight decrease in brake power of about $10 \%$ and a decrease in BSFC of about $15 \%$ at $(50 \ldots 80) \%$ cylinder filling ratio settling. CNG gave a $1.6 \%$ increase in thermal efficiency and an approx. $24 \%$ higher temperature resulting in a $40 \%$ increase in $\mathrm{NO}_{\mathrm{x}}$ emissions. The other components of the exhaust gas $\left(\mathrm{HC}, \mathrm{CO}, \mathrm{O}_{2}\right.$, and $\left.\mathrm{CO}_{2}\right)$ were significantly lower with CNG fueling than with gasoline fueling [17]. Engines operating in lean-burn mode became a problem. In [18], there was research with CNG engine development procces it was found that feeding the SI engine with CNG resulted in a $15 \%$ decrease in brake power and about $16 \%$ decrease in BSFC. The thermal efficiency increased by $10 \%$ with respect to gasoline supply. CNG fueling resulted in a $30 \%$ increase in $\mathrm{NO}_{\mathrm{x}}$ emissions and a $12 \%$ lower HC emissions and up to $90 \%$ lower $\mathrm{CO}$ emissions comparing to petrol data results. Another challenge facing CNG power is downsizing. By using the right materials and processing targeted for $\mathrm{CNG}$ power, $\mathrm{CO}_{2}$ savings of up to $50 \%$ at peak power and 20-40\% in the driving cycle area, including RDE, can be achieved for this type of engine [18].

Subsequent analysis of $\mathrm{CO}_{2}$ emissions over the TTW cycle showed that it is most favorable for gasoline/CNG fueled engines, which consume $28.8 \%$ and $6.7 \%$ less $\mathrm{CO}_{2}$ than gasoline/LPG and diesel vehicles, respectively [19]. Comparing this to the other multifuel configurations, the diesel/CNG $\mathrm{CO}_{2}$ emissions are $13.5 \%$ lower than the gasoline/LPG and even $1.5 \%$ lower than the diesel vehicles considered in this study. The lowest fuel cost per $\mathrm{km}$ was achieved by gasoline/CNG vehicles, $32 \%$ and $35 \%$ less than gasoline/LPG and diesel vehicles, respectively.

For CI engines, there are two ways to run on $\mathrm{CNG}$. The first one is to use both fuels simultaneously and cocombustion diesel fuel together with CNG. Increasing the share of CNG co-combusted with diesel fuel results in delayed auto-ignition of the mixture and shortens the combustion time. Stabilization of engine operation is obtained at (30...45)\% CNG share. In this range, HC, CO and significantly $\mathrm{CO}_{2}$ emission of the dual-fuel engine are reduced [20]. Additionally, in the low load range, a delay in CNG injection timing $\left(130^{\circ} \mathrm{ATDC}\right.$ - crank angle degree manually set in ecu algorithm) is proposed resulting in an increase in cylinder pressure and an increase in HRR with a decrease in $\mathrm{HC}, \mathrm{CO}$ and PM emissions [21]. The optimal CNG injection timing for a dual-fuel engine at low load was considered to be $110^{\circ} \mathrm{CA}$. In addition to downsizing, work is also being done on other engine designs, such as the RI-CNG having a sub-chamber above the main combustion chamber. By modifying the $\mathrm{CI}$ engine by adding a CVC, an attempt was made to solve the problem of removing gas remaining in the subchamber from the previous cycle. Preliminary tests gave promising results, both in terms of engine performance indicators and exhaust emissions indicating the prospects for further modifications [22]. 
The second way to use CNG as a fuel in a CI engine is a conversion involving a switch to SI operation. Besides the obvious advantages of this way of powering, there is one problem related to the fact that the SI engine should reach at least $1500 \mathrm{rev} / \mathrm{min}$ for the operating speed range [23], which for some CI engines undergoing conversion lies in the high speed range. In [24], a study of bus engines was presented in which one was powered by CNG only and did not have any aftertreatment systems, and the other was powered by diesel by equipping it with OC and then with DPF. It was found that transient emissions were significantly higher than steady state emissions. Emissions of toxic compounds from the CNG-fueled engine (without after-treatment systems) and from the low-sulfur diesel vehicle fitted with DPF were lower than from the low-sulfur diesel vehicle fitted with OC. A comprehensive review of separate as well as simultaneous $\mathrm{CO}$ and $\mathrm{CH}_{4}$ oxidation reactions to control emissions from $\mathrm{CNG}$ vehicles is presented in [25]. PM emission is also a very important emission issue. In [26], a study was conducted on $\mathrm{PM}>23 \mathrm{~nm}$ emissions for $\mathrm{CNG}$ fueled engines. They were shown to suck an order of magnitude lower than for GDi and PFI engines. Analysis of particle size distributions showed that in many cases they are below the regulated limit of $23 \mathrm{~nm}$ (Euro 6b) and even below $10 \mathrm{~nm}$. In addition to testing for homologation legislation, a number of non-regulated pollutants $\left(\mathrm{NH}_{3}, \mathrm{~N}_{2} \mathrm{O}, \mathrm{CH}_{4}\right.$ and $\left.\mathrm{HCHO}\right)$ are also being tested, which is important for CNG fueling. Using an FTIR instrument, it was possible to comprehensively evaluate these constituents from Euro 6d, Euro 6c and Euro 6d-TEMP vehicles operating in CI, SI modes and powered by $\mathrm{CNG}$ during $\mathrm{RDE}$ tests [27]. $\mathrm{NH}_{3}$ emissions were up to $49 \mathrm{mg} / \mathrm{km}$ for the SI engine, up to $69 \mathrm{mg} / \mathrm{km}$ for the CNGfueled engine and up to $17 \mathrm{mg} / \mathrm{km}$ for the CI engine with $\mathrm{SCR}$. On the other hand, $\mathrm{N}_{2} \mathrm{O}$ and $\mathrm{CH}_{4}$ emissions were up to $9.8 \mathrm{gCO}_{2} \mathrm{eqv} / \mathrm{km}$ for the $\mathrm{CI}$ engine with DOC, LNT and ASC.

The aim of the study was to evaluate the possibility of conversion of a CI engine fueled classically with diesel fuel to operate in the SI mode when fueled with CNG. In the research, apart from the possibility of conversion itself through appropriate modifications within the engine necessary for its operation, the influence of the presence of catalysts on HC conversion was analyzed. The study was limited to two different designs of catalysts operating at different exhaust gas temperatures.

\section{Object of the research}

The object of the research was a Cummins 6BT engine. The basic technical data of the tested engine in its original version (fueled with diesel oil) have been presented in Table 1.
Table 1

The technical data of the original Cummins 6BT engine. Data taken from Ref. [28]

\begin{tabular}{|l|l|}
\hline \multicolumn{1}{|c|}{ Parameter } & \multicolumn{1}{c|}{ Value } \\
\hline - model & $\begin{array}{l}6 \mathrm{BT} / \mathrm{R} 6 / 12 \mathrm{~V}, 4 \text {-stroke, } \\
\text { turbocharged }\end{array}$ \\
\hline - engine displacement & $5.9 \mathrm{~cm}^{3}$ \\
\hline - max. power at engine speed & $215 \mathrm{~kW}$ at $2200 \mathrm{rev} / \mathrm{min}$ \\
\hline - max. torque at engine speed & $597 \mathrm{~N} \cdot \mathrm{m}$ at $\mathrm{rev} / \mathrm{min}$ \\
\hline - bore & $102 \mathrm{~mm}$ \\
\hline - stroke & $119 \mathrm{~mm}$ \\
\hline - compression ratio & $17: 1$ \\
\hline
\end{tabular}

The Cummins 6BT engine has undergone numerous modifications in order to adapt it to run on compressed natural gas (CNG). A sequential gas injection system and an ignition system controlled by a STAG $600 \mathrm{MF}$ system were installed. The compression ratio was also lowered from 17:1 to $11.5: 1$ by replacing the pistons. An electronic throttle body BOSCH 0280780009 was installed to regulate the degree of filling the cylinders. In the exhaust system, a WBO lambda probe Bosch LSU 4.9 was installed to evaluate the combustion process. The research course included a comparison of two different catalytic converters, which also had to be adapted to the connections resulting from the design of the exhaust system.

Two three-functional catalysts differing in mass of particular conversion sections were used in tests, both tested catalysts being characterized by the same tubule density coefficient at the level of 300 CPSI. In the tested catalyst No. 1 (Cat_1) the monolithic conversion section $s_{1}$ has a mass of $800 \mathrm{~g}$, section $\mathrm{s}_{2}$ has a mass of $1000 \mathrm{~g}$, section $s_{3}$ has a mass of $1000 \mathrm{~g}$. For catalyst No. 2 (Cat_2) respectively the masses of the sections are $s_{1}=800 \mathrm{~g}, s_{2}=600 \mathrm{~g}, s_{3}=600 \mathrm{~g}$.

\section{Research methodology}

In the course of the study, a SuperFlow SF-902 water-braked dynamometer was used to load the Cummins 6BT engine. HC emissions were evaluated using a Maha MGT-5 analyzer. The exhaust gas temperature after the catalytic converter was measured using a T-208P EGT probe connected to the exhaust gas temperature controller of a Stag $600 \mathrm{MF}$ engine controller.

The SuperFlow SF-902 dynamometer operated in a mode of two control parameters. The first one was the temperature after the catalyst (set for two variants), and the second one was the variable engine speed (900...1900) rev/min. At particular rotational speeds (step every $100 \mathrm{rev} / \mathrm{min}$ ) and fixed values of exhaust temperatures and of values $\mathrm{HC}$ for both catalyst types.

Basic technical data of the measurement equipment have been presented in Table 2 .

Table 2

Parameters of the measuring equipment. Data taken from Ref. [29,30]

\begin{tabular}{|l|c|c|c|}
\hline \multicolumn{1}{|c|}{ Parameter } & Measurement device & Range & Accuracy \\
\hline Rotation speed: $n, \mathrm{rev} / \mathrm{min}$ & SuperFlow SF-902 & $0-9,000$ & \pm 1 \\
\hline Torque: $M, \mathrm{~N} \cdot \mathrm{m}$ & SuperFlow SF-902 & $0-1,627$ & $\pm 0.25 \%$ \\
\hline Power: $P, \mathrm{~kW}$ & SuperFlow SF-902 & $0-1,119$ & $\pm 0.25 \%$ \\
\hline Hydrocarbons: HC, ppm & Maha MGT-5 & $0-40000$ (methane) & \pm 12 \\
\hline Temperature: $T,{ }^{\circ} \mathrm{C}$ & STAG 600 MF EGT controller & $0-1150$ & \pm 2.5 \\
\hline
\end{tabular}




\section{Results and discussion}

In the majority of scientific papers, comparative studies of power systems are carried out by comparison on the basis of full load engine characteristics and performance $[31,32]$, or in the course of tests in accordance with legislative requirements (NEDC, WLTP and RDE) [33, 34]. Some publications include regulatory characteristics with varying degrees of control and different choices of analyzed parameters [35]. However, all these cases do not allow to create guidelines for comprehensive engine evaluation. Therefore, further work on regulatory characteristics in areas not yet in the spectrum is indicated. Based on this assumption and taking into account achievements of other researchers, an attempt was made to assess the degree of $\mathrm{HC}$ conversion in catalytic converters of various designs responsible for cleaning engine exhaust gases used for CNG fueling at fixed exhaust gas temperatures and variable engine rotational speed. Very important in this case was the software controlling the engine operating parameters to enable the test cycle.

In. Fig. 1 shows the temperature values for Cat_1 and Cat_2 tests. In spite of slight variations over the range of engine crankshaft speeds tested $(900 \ldots 1900) \pm 1 \mathrm{rev} / \mathrm{min}$, the average exhaust gas temperature after the catalyst was $T_{\text {Cat } \_1}=513 \pm 2.5^{\circ} \mathrm{C}$ for Cat_1, while Cat_2 was $T_{\text {Cat_2 }}=432 \pm 2.5^{\circ} \mathrm{C}$. Although the average temperatures are slightly different from the set-point, they should be considered representative.

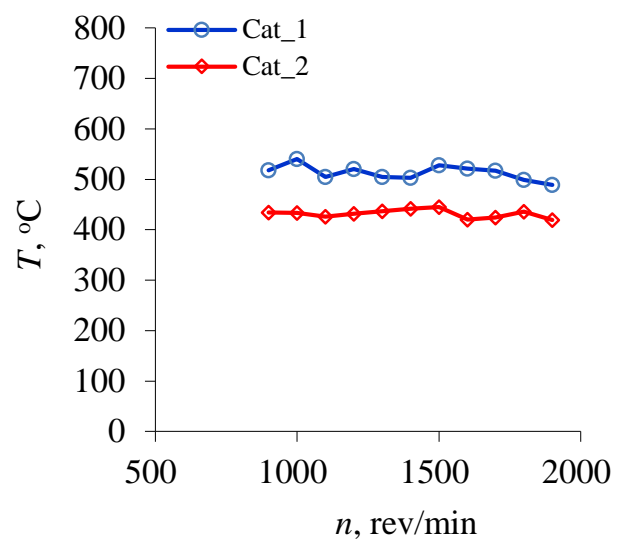

Fig. 1 Values of exhaust gas temperatures for both tested catalysts

In order to provide the exhaust gas temperature required by the test range, it was necessary to vary external indicators such as power $P$ and torque $M$ (Fig. 2). It should be emphasized here that the goal was to maintain the exhaust gas temperature and speed while adjusting the engine power stage and load. Maintaining the exhaust gas temperature at around $500 \pm 2.5^{\circ} \mathrm{C}$ with the Cat_1 test (Fig. 2) was accompanied by an increase in the values of $P$ and $M$. The maximum values were about $70 \%$ higher than with the Cat_2 test at $500 \pm 2.5^{\circ} \mathrm{C}(n=1300 \pm 1 \mathrm{rev} / \mathrm{min})$. There is a gradual decrease in the external indices at Cat_2, while significant fluctuations were observed at Cat_1. This confirms the supposition of a significant energy requirement to raise the exhaust gas temperature.

Regardless of the type of catalyst used and the exhaust gas temperature, HC emissions both upstream and downstream of the catalyst increase with increasing speed (Fig. 3). The nature of the HC increase has a larger gradient for the case of Cat_1 and an exhaust gas temperature of $500 \pm 2.5^{\circ} \mathrm{C}$. Also for this case, there are larger differences in emissions upstream and downstream of the catalyst.

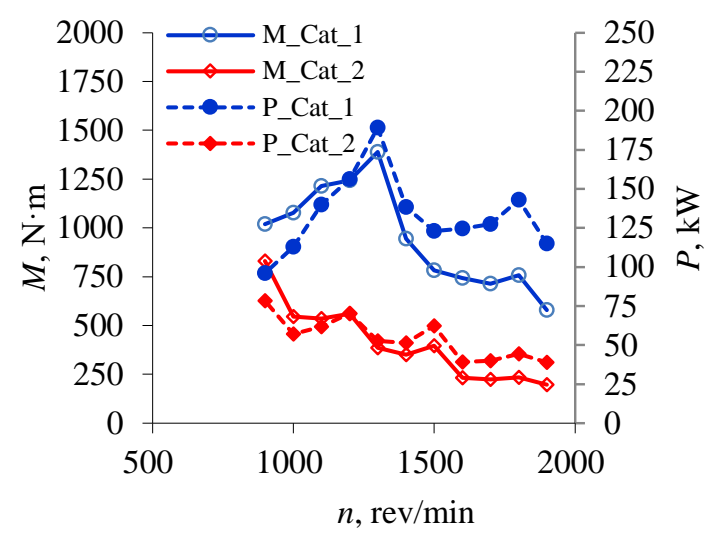

Fig. 2 Variability of external indicators, torque and power for both catalysts and different exhaust gas temperatures

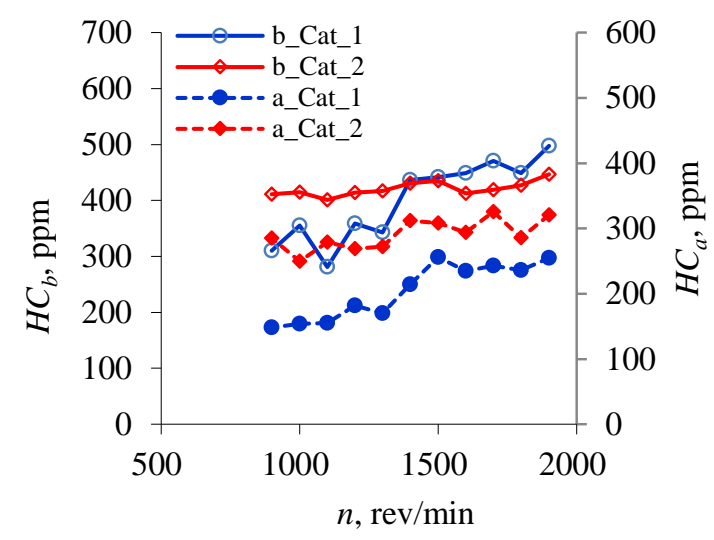

Fig. 3 Hydrocarbon emission values before and after the catalytic converter for both variants of catalytic converters and exhaust gas temperatures

In the final stage of analysis, on the basis of differences in $\mathrm{HC}$ emission by and behind the tested catalysts, $\mathrm{HC}$ conversion degree was referred to. In the case of Cat_1 operating at the exhaust gas temperature of $500 \pm 2.5^{\circ} \mathrm{C}$, set by the conditions of the tests, the average value of the conversion degree in the tested range of rotational speeds (900...1900) $\pm 1 \mathrm{rev} / \mathrm{min}$ was $52 \%$. In the case of Cat_2, operating at $400 \pm 2.5^{\circ} \mathrm{C}$, it was $31 \%$. The minimum $\mathrm{HC}$ conversion was found for the Cat_2 case at $1700 \pm 1$ rev/min and was $22 \%$. For the limiting case at $1400 \pm 1 \mathrm{rev} / \mathrm{min}$, Cat_1 showed $23.5 \%$ higher HC conversion than Cat_2. The minimum value in the difference of $\mathrm{HC}$ conversion rate in favour of Cat_2 was found at $1500 \pm 1 \mathrm{rev} / \mathrm{min}$ and it was $12.8 \%$.

Summarizing the results of research and analysis, it should be stated that it is possible to adapt the CI engine powered by classical diesel fuel to operate in the SI mode powered by CNG. It is necessary to make suitable modifications regarding the change of compression ratio in order to prevent knocking combustion, installation of gas supply system and ignition system. The installation of an air damper is also necessary to control the filling level of the cylinders. Comparison of two structurally different Cat_1 and Cat_2 catalysts operating at different exhaust gas temperatures of $500 \pm 2.5^{\circ} \mathrm{C}$ and $400 \pm 2.5^{\circ} \mathrm{C}$ gives in the limiting 
case $23.5 \%$ difference in $\mathrm{HC}$ conversion. The minimum conversion value in the study area was recorded for Cat_2 at $1700 \pm 1 \mathrm{rev} / \mathrm{min}$ and was $22 \%$.

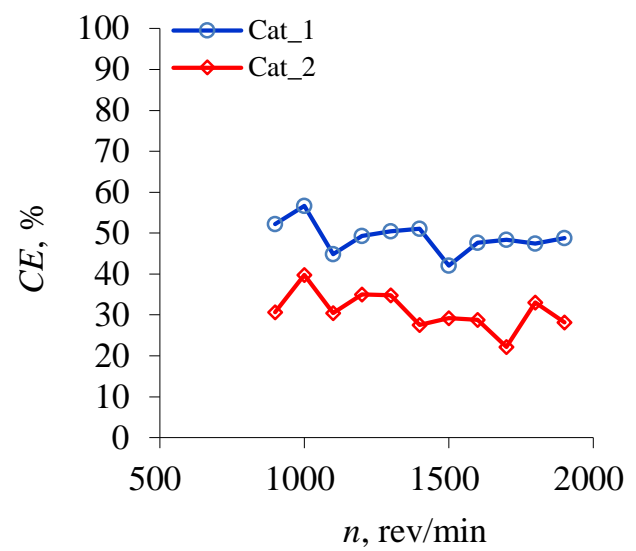

Fig. 4 HC conversion rate for both variants of catalytic converters at different exhaust gas temperatures

The research topics covered in this study are areas outside of the main trends in the field so it is difficult to refer to studies by other researchers. The results presented here are part of a comprehensive study on conversion of CI engines to SI operation using alter-native fuels. One more fact must be kept in mind when converting a CI engine to SI operation. SI engines belong to the group of high-speed engines, so their operating speed should be higher than $1500 \pm 1 \mathrm{rev} / \mathrm{min}$, which can be a problem for conversion.

\section{Conclusions}

1. Conversion of a diesel-powered CI engine to a CNG-powered SI engine is possible by changing the compression ratio, using an air throttle and dedicated ignition and power systems.

2. Tests carried out at fixed/decreased exhaust temperature $(400$ and 500$) \pm 2.5^{\circ} \mathrm{C}$ and variable speed $(900 \ldots 1900) \pm 1 \mathrm{rev} / \mathrm{min}$ allowed to evaluate the degree of $\mathrm{HC}$ conversion in catalytic converters of various designs.

3.Catalyst 1 operating at $500 \pm 2.5^{\circ} \mathrm{C}$ showed $23.5 \%$ higher conversion than catalyst 2 operating at a lower temperature $\left(400 \pm 2.5^{\circ} \mathrm{C}\right)$ in the investigated range of rotational speeds.

4. In order to be able to achieve the required exhaust temperature in the test course, it was required that the engine generated up to $70 \%$ higher external indicator values in the form of power at the required temperature of $500 \pm 2.5^{\circ} \mathrm{C}$ in the catalyst 1 tests, relative to the catalyst 2 test at $400 \pm 2.5^{\circ} \mathrm{C}$.

\section{Acknowledgment}

This research was financed through subsidy of the Ministry of Science and Higher Education of Poland for the discipline of mechanical engineering at the Faculty of Mechanical Engineering Bialystok University of Technology WZ/WM-IIM/4/2020.

\section{References}

1. García, A.; Monsalve-Serrano, J.; Villalta, D.; Guzmán-Mendoza, M. 2020. Methanol and OMEx as fuel candidates to fulfill the potential EURO VII emissions regulation under dual-mode dual-fuel combustion, Fuel 287: 119548.

http://dx.doi.org/10.1016/j.fuel.2020.119548.

2. Clairotte, M.; Suarez-Bertoa, R.; Zardini, A.A.; Giechaskiel, B.; Pavlovic, J.; Valverde, V.; Ciuffo, B.; Astorga, C. 2020. Exhaust emission factors of greenhouse gases (GHGs) from European road vehicles, Environmental Sciences Europe 32: 125. http://dx.doi.org/10.1186/s12302-020-00407-5.

3. Ziegler, M. 2020. The Road to Euro 7, MTZ worldwide 81: $14-15$, http://dx.doi.org/10.1007/s38313-020-0243-5.

4. Varella, R. A.; Duarte, G.; Baptista, P.; Sousa, L.; Mendoza Villafuerte, P. 2017. Comparison of Data Analysis Methods for European Real Driving Emissions Regulation, SAE Technical Papers 2017-01-0997. http://dx.doi.org/10.4271/2017-01-0997.

5. Dimitrova, Z.; Maréchal, F. 2015. Gasoline hybrid pneumatic engine for efficient vehicle powertrain hybridization, Applied Energy 151: 168-177. http://dx.doi.org/10.1016/j.apenergy.2015.03.057.

6. Brejaud, P.; Higelin, P.; Charlet, A.; Colin, G.; Chamaillard, Y. 2011. Échange de chaleur convectif dans un moteur hybride pneumatique, Oil and Gas Science and Technology 66: 1035-1051. http://dx.doi.org/10.2516/ogst/2011121.

7. Gül, T.; Kypreos, S.; Turton, H.; Barreto, L. 2009. An energy-economic scenario analysis of alternative fuels for personal transport using the Global Multiregional MARKAL model (GMM), Energy 34: 14231437. http://dx.doi.org/10.1016/j.energy.2009.04.010.

8. Warguła, L.; Waluś, K.J.; Krawiec, P. 2018. Small engines spark ignited (SI) for non-road mobile machinery - Review, In Proceedings of the Transport Means - Proceedings of the International Conference: 585-591.

9. Jin, J.; Feng, M. 2003. Research and development of marine LPG engines, In Proceedings of the Energy and the Environment - Proceedings of the International Conference on Energy and the Environment: 1.

10. Pielecha, I.; Sidorowicz, M. 2021. Effects of mixture formation strategies on combustion in dual-fuel engines - a review, Combustion Engines 184(1): 30-40. http://dx.doi.org/doi:10.19206/CE-134237.

11. Mieczkowski, G. 2019. Static electromechanical characteristics of piezoelectric converters with various thickness and length of piezoelectric layers, Acta Mechanica et Automatica 13: 30-36. http://dx.doi.org/10.2478/ama-2019-0005.

12. Stan, C. 2002. Future trends in the development of spark ignition engines, MTZ Worldw 63: 27-30. https://doi.org/10.1007/BF03227579.

13. Raslavičius, L.; Keršys, A.; Mockus, S.; Keršiene, N.; Starevičius, M. 2014. Liquefied petroleum gas (LPG) as a medium-term option in the transition to sustainable fuels and transport, Renewable and Sustainable Energy Reviews 32: 513-525. http://dx.doi.org/10.1016/j.rser.2014.01.052.

14. Khan, M. I.; Yasmeen, T.; Khan, M. I.; Farooq, M.; Wakeel, M. 2016. Research progress in the development of natural gas as fuel for road vehicles: A bibliographic review (1991-2016), Renewable and Sustainable Energy Reviews 66: 702-741. 
http://dx.doi.org/10.1016/j.rser.2016.08.041.

15. Borawski, A. 2015 Modification of a fourth generation LPG installation improving the power supply to a spark ignition engine, Eksploatacja i Niezawodnosc 17: 1-6. http://dx.doi.org/10.17531/ein.2015.1.1.

16. Liu, Y.; Helfand, G.E. 2009. The Alternative Motor Fuels Act, alternative-fuel vehicles, and greenhouse gas emissions, Transportation Research Part A: Policy and Practice 43: 755-764. http://dx.doi.org/10.1016/j.tra.2009.07.005.

17. Jahirul, M. I.; Masjuki, H. H.; Saidur, R.; Kalam, M. A.; Jayed, M. H.; Wazed, M. A. 2010. Comparative engine performance and emission analysis of CNG and gasoline in a retrofitted car engine. Applied Thermal Engineering 30(14-15): 2219-2226.

http://dx.doi.org/10.1016/j.applthermaleng.2010.05.037

18. Hall, J.; Bassett, M.; Hibberd, B.; Streng, S. 2016. Heavily downsized demonstrator engine optimised for CNG operation, SAE International Journal of Engines 9(4): 2250-2261.

http://dx.doi.org/10.4271/2016-01-2363.

19. Stanojevic, N.; Vasic, M.; Popovic, V. 2020. The contribution of CNG powered vehicles in the transition to zero emission mobility - example of the light commercial vehicles fleet, Thermal Science: 241-241. http://dx.doi.org/10.2298/tsci200721241s

20. Jamrozik, A.; Tutak, W.; Grab-Rogaliński, K. 2019. An experimental study on the performance and emission of the diesel/CNG dual-fuel combustion mode in a stationary CI engine, Energies 12(20): 3857. http://dx.doi.org/10.3390/en12203857.

21. Yuvenda, D.; Sudarmanta, B.; Wahjudi, A.; Muraza, O. 2020. Improved combustion performances and lowered emissions of CNG-diesel dual fuel engine under low load by optimizing CNG injection parameters, Fuel 269: 117202. http://dx.doi.org/10.1016/j.fuel.2020.117202.

22. Ha, D.; Park, J.; Yeom, J.; Ha, J.; Chung, S. 2007. Study on combustion and emission characteristics of CNG fueled RI-engine. In Proceedings of the SAE Technical Papers 2007-01-3621. http://dx.doi.org/10.4271/2007-01-3621.

23. B. Heywood, J. 2015. Internal Combustion Engine Fundamentals Second Edition; 2015; Vol. 7;

24. Kado, N. Y.; Okamoto, R. A.; Kuzmicky, P. A.; Kobayashi, R.; Ayala, A.; Gebel, M. E.; Rieger, P. L.; Maddox, C.; Zafonte, L. 2005. Emissions of toxic pollutants from compressed natural gas and low sulfur diesel-fueled heavy-duty transit buses tested over multiple driving cycles, Environmental Science and Technology 39: 7638-7649.

http://dx.doi.org/10.1021/es0491127.

25. Trivedi, S.; Prasad, R.; Mishra, A.; Kalam, A.; Yadav, P. 2020. Current scenario of CNG vehicular pollution and their possible abatement technologies: an overview, Environmental Science and Pollution Research 27: 39977-40000. http://dx.doi.org/10.1007/s11356-020-10361-7.

26. Toumasatos, Z.; Kontses, A.; Doulgeris, S.; Samaras, Z.; Ntziachristos, L. 2021. Particle emissions measurements on CNG vehicles focusing on Sub-23nm, Aerosol Science and Technology 55: 182-193. http://dx.doi.org/10.1080/02786826.2020.1830942

27.Suarez-Bertoa, R.; Pechout, M.; Vojtíšek, M.;
Astorga, C. 2020. Regulated and non-regulated emissions from euro 6 diesel, gasoline and $\mathrm{CNG}$ vehicles under real-world driving conditions, Atmosphere 11: 25704.

http://dx.doi.org/10.3390/atmos11020204.

28. Cummins 6BT / 6BTA 5.9 Specifications Available online: https://www.sbmar.com/engine-info/cummins6bta-specifications/ [accessed on Apr 2, 2021].

29. SuperFlow SF-902 - technical data Available online: https://superflow.com/product/sf-902s/ [accessed on Mar 5, 2021].

30. Maha MGT 5, Emission Measurement Technology Available online: https://www.maha.de/cps/rde/xbcr/ maha_de/TD_MAHA_MGT_5_VP135109_EN.pdf [accessed on May 10, 2020].

31. Szpica, D. 2019. Coefficient of engine flexibility as a basis for the assessment of vehicle tractive performance, Chinese Journal of Mechanical Engineering (English Edition) 32: 39. http://dx.doi.org/10.1186/s10033-019-0352-8.

32. Szpica, D.; Piwnik, J.; Sidorowicz, M. 2014. The motion storage characteristics as the indicator of stability of internal combustion engine-receiver cooperation, Mechanika 20: 108-112. http://dx.doi.org/10.5755/j01.mech.20.1.6592.

33. Bielaczyc, P.; Woodburn, J. 2019. Trends in Automotive Emission Legislation: Impact on LD Engine Development, Fuels, Lubricants and Test Methods: a Global View, with a Focus on WLTP and RDE Regulations, Emission Control Science and Technology 5: 86-98. http://dx.doi.org/10.1007/s40825-019-0112-3

34. Beik, Y.; Dziewiątkowski, M.; Szpica, D. 2020. Exhaust emissions of an engine fuelled by petrol and Liquefied Petroleum Gas with control algorithm adjustment, SAE International Journal of Engines 13(5): 739-759. http://dx.doi.org/10.4271/03-13-05-0047.

35. Puškár, M.; Jahnátek, A.; Kádárová, J.; Šoltésová, M.; Kovanič, L'.; Krivosudská, J. 2019. Environmental study focused on the suitability of vehicle certifications using the new European driving cycle (NEDC) with regard to the affair "dieselgate" and the risks of NO x emissions in urban destinations, Air Quality, Atmosphere and Health 12: 251-257. http://dx.doi.org/10.1007/s11869-018-0646-5

\section{Dziewiątkowski, D. Szpica}

\section{EVALUATION OF THE CONVERSION RATE REGARDING HYDROCARBONS CONTAINED IN THE EXHAUST EASES OF AN ENGINE FUELLED WITH COMPRESSED NATURAL GAS (CNG) USING DIFFERENT CATALYSTS OPERATING AT DIFFERENT TEMPERATURES}

S u m m a r y

Further restrictions on the use of compression-ignition engines in transportation are prompting the search for adaptations to run on other fuels. One of the most popular alternative fuels is Compressed Natural Gas (CNG), which 
due to its low carbon content can be competitive with classical fuels. This paper presents the results of testing a Cummins 6BT compression ignition engine that has undergone numerous modifications to convert to $\mathrm{CNG}$ power. The sequential gas injection system and the ignition system were installed in this engine. The compression ratio was also lowered from 16.5 to 11.5 by replacing the pistons. Tests conducted on an engine dynamometer were to show the differences in emission and conversion in the catalyst of hydrocarbons contained in the exhaust gases. Two structurally different catalysts operating at different exhaust temperatures (400 and 500$) \pm 2.5^{\circ} \mathrm{C}$ were used. The catalyst operating at $500 \pm 2.5^{\circ} \mathrm{C}$ showed a $23.5 \%$ higher conversion rate than the catalyst operating at a lower temperature in the range of the speed range tested. Also the external indicators, such as power and torque for the case of higher operating temperature took values over $70 \%$ higher. The research is one of the stages of a comprehensive assessment of the possibility of adaptation of compression ignition engines to $\mathrm{CNG}$-only fueling.

Keywords: mechanical engineering, combustion engines, alternative fuel supply, CNG, research.

Received April 20, 2021

Accepted December 07, 2021

This article is an Open Access article distributed under the terms and conditions of the Creative Commons Attribution 4.0 (CC BY 4.0) License (http://creativecommons.org/licenses/by/4.0/). 